\title{
The cognitive representation of brands
}

Citation for published version (APA):

Dawar, N. (2006). The cognitive representation of brands. Maastricht University. https://doi.org/10.26481/spe.20060612nd

Document status and date:

Published: 12/06/2006

DOI:

10.26481/spe.20060612nd

Document Version:

Publisher's PDF, also known as Version of record

\section{Please check the document version of this publication:}

- A submitted manuscript is the version of the article upon submission and before peer-review. There can be important differences between the submitted version and the official published version of record.

People interested in the research are advised to contact the author for the final version of the publication, or visit the DOI to the publisher's website.

- The final author version and the galley proof are versions of the publication after peer review.

- The final published version features the final layout of the paper including the volume, issue and page numbers.

Link to publication

\footnotetext{
General rights rights.

- You may freely distribute the URL identifying the publication in the public portal. please follow below link for the End User Agreement:

www.umlib.nl/taverne-license

Take down policy

If you believe that this document breaches copyright please contact us at:

repository@maastrichtuniversity.nl

providing details and we will investigate your claim.
}

Copyright and moral rights for the publications made accessible in the public portal are retained by the authors and/or other copyright owners and it is a condition of accessing publications that users recognise and abide by the legal requirements associated with these

- Users may download and print one copy of any publication from the public portal for the purpose of private study or research.

- You may not further distribute the material or use it for any profit-making activity or commercial gain

If the publication is distributed under the terms of Article $25 \mathrm{fa}$ of the Dutch Copyright Act, indicated by the "Taverne" license above, 


\title{
The Cognitive Representation of Brands
}

\author{
Niraj Dawar \\ Universiteit Maastricht, \\ June 12, 2006
}

Rector Magnificus, Ladies and Gentlemen:

I am honored to be here.

A few months ago, when Dean Lemmink sent me an e-mail to invite me to do this talk, he suggested that I include and highlight the implications for society of my research. With brands as a topic of study, it is hard to avoid that.

Consider the brands with which you have interacted since this morning. List them mentally. There are many, including many for products and services you have used, as well as advertisements to which you have been exposed, and brands you've seen others consume.

The ubiquity of brands is due to the many vital functions they perform for both sellers and buyers.

Consider the functions that brands perform for sellers. They help sellers position their wares in the marketplace, both for the consumer (e.g. Volvo is safety) and to differentiate from competitors. Brands also help the seller turn sales transactions into revenue streams by allowing them to capture the rewards of consumer loyalty. Brands allow sellers to charge a price premium over generic products. Brands also allow firms to focus their activities on a particular position or promise in the marketplace, making much more efficient use of their resources. And finally brands are a valuable asset that can be traded for money.

For consumers, the functions that brands perform are equally numerous and vital. Buyers rely on brands to reduce the risk of purchases. Brands also make it easier for buyers to buy, simplifying complex shopping environments. Brands also allow buyers to repurchase products and services with which they are satisfied. Brands allow buyers to match benefits to needs - those seeking a safe automobile are attracted to a Volvo. Finally, brands serve as a signal of quality that consumers use to simplify their purchases.

These vital functions allow brands to serve as a platform on which transactions between buyers and sellers take place. 
But where does this platform reside? One answer tot his question, is that brands reside in the consumers' mind. They are a fictitious entity that the buyer and seller have agreed to endow with meaning. From a researcher's perspective, they are a hypothetical construct.

Looking at how Psychologists represent cognitive entities, brands have been variously conceptualized as associative networks, category structures, or even relationships of varying length between the buyer and seller.

One type of cognitive representation of brands is to think of them as embedded in a network of conceptual nodes, such as Nike in this example.

So here is what the sandbox in which I play looks like. The cognitive representation of brands can be studied by examining (i) the prior beliefs that consumers hold about brands and related entities; (ii) the impact of external information on these beliefs; (iii) the nature of the processing that the external information is subjected to; and (iv) the outcomes, for example, updated priors or behavior changes.

The toys in this sandbox, or the variables that I play with include, for example, consumers' prior familiarity, prior expectations, or existing corporate and brand associations as prior beliefs; Advertising, news and other sources of external information as external stimuli; retrieval, attributions, and inferences as processes; and updated brand equity and brand evaluations as outcomes.

In terms of external stimuli, I have taken to using negative information because it is salient, and therefore has strong and easily detectable effects. Negative information stimuli are less common than positive information in research on marketing where advertising and other positive claims tend to be the stimuli of interest. I have specifically used negative information emanating from product-harm crises, environmental disasters, and terrorist incidents, although such information could also come from other sources such as corporate scandals.

In one study, I examined the effects of prior consumer familiarity on perceptions of responsibility of a brand that was used as an accessory in a terrorist attack. Ryder truck had been concerned enough about their brand image in the wake of the Oklahoma City bombing to conduct a national phone survey to determine consumer perceptions. The results of the survey showed that only a small minority of consumers believed that Ryder bore 'some' responsibility in the terrorist incident. But interestingly, those who knew the brand name Ryder from having rented their trucks in the previous 5 years were only a quarter as likely to attribute responsibility to the company as those who had not rented a truck from the company.

Another study examined the effects of unrelated prior beliefs about the company, such as beliefs about Corporate Social Responsibility, and determined whether these had a carryover effect on consumers' attributions of a product-harm crisis. The findings show that on each of three dimensions of blame, consumers are far more likely to make attributions of responsibility to companies that have a poor record on CSR than those that 
have a good record on CSR. An implication of this research is that the CSR reputations that companies build can act as an insurance policy in times of product-harm crisis.

Prior beliefs moderate the interpretation of external information. These prior beliefs can act as a positive filter through which negative information is interpreted, affording companies that have prior expectations the benefit of the doubt.

Further research that colleagues and I are conducting in this area includes an examination of the effects of cognitive processing capacity on the nature of attributions made, and the spillover effects of product-harm crises in brand portfolios.

Thank you. Ik heb gezegd. 